\section{Revisiting childhood pneumonia in low-recourse setting hospitals}

\author{
Karimeldin MA Salih*
}

Associate Professor, Department of Paediatrics, College of Medicine, University of Bisha, KSA

\section{Abstract}

Introduction: Pneumonia, defined as infection of lung parenchyma, is associated with severe complications especially in the very young and old patients. It is the world's leading cause of childhood mortality. The World Health Organization (WHO) classification and guidelines are commonly used in Sudan in the diagnosis and management of pneumonia patients. This review was the outcome of some researches done in Sudan by the author and his colleagues. Management Systems were evaluated to give complete end to end solutions for serving patients along with their records in hospitals and clinics in Sudan. The objective of the study was: To reflect author experience in management of childhood pneumonia in Sudan and to determine feasible, affordable approach to pneumonia in Sudan.

Methodology: Searching through PubMed for the author publication and review of publication by author in Sudan regarding management of pneumonia.

Conclusion: Simple tests like chest X-ray, high WBC high-reactive protein, together with high temperature can predict the need for urgent blood culture. Antibiotic treatment for childhood pneumonia weather that recommended by WHO, b-lactam inhibitors or $3^{\text {rd }}$ generation cephalosporin has the same outcome.

\section{More Information}

*Address for Correspondence: Karimeldin MA Salih, Associate Professor, Department of Paediatrics, College of Medicine, University of Bisha, KSA

Email: Karimeldin_salih@hotmail.com

Submitted: May 24, 2021

Approved: July 09, 2021

Published: July 12, 2021

How to cite this article: Salih KMA. Revisiting childhood pneumonia in low-recourse setting hospitals. J Adv Pediatr Child Health. 2021; 4: 062-066.

\section{DOI: 10.29328/journal.japch.1001035}

Copyright: @ 2021 Salih KMA. This is an open access article distributed under the Creative Commons Attribution License, which permits unrestricted use, distribution, and reproduction in any medium, provided the original work is properly cited.

\section{Check for updates}

๑) OPEn Access

\section{Introduction}

Pneumonia is a major killer worldwide among children less than five-year, proper management help in decreasing deaths from million in eighties to around million deaths in 2013 [1-3]. WHO recommend first line treatment with injectable ampicillin and gentamicin, where $3^{\text {rd }}$ generation cephalosporin as a second choice for treatment of severe pneumonia [1-3].

Pneumonia is an inflammation in one or both of the lungs that is caused by a viral or bacterial infection [4]. The inflammation interferes with the body's ability to deliver oxygen and remove carbon dioxide from the blood [5].

The signs and symptoms of pneumonia are often nonspecific and widely vary based on the patient's age and the infectious organisms involved.

Observing the child's respiratory effort during a physical exam is an important first step in diagnosing pneumonia [4]. The World Health Organization (WHO) respiratory rate thresholds for identifying children with pneumonia are as follows: [4].
- Children younger than 2 months: Greater than or equal to 60 breaths/min

- Children aged 2-11 months: Greater than or equal to 50 breaths/min

- Children aged 12-59 months: Greater than or equal to 40 breaths/min

Newborns with pneumonia commonly present with poor feeding and irritability, as well as tachypnea, retractions, grunting, and hypoxemia [4].

Cough is the most common symptom of pneumonia in infants, along with tachypnea, retractions, and hypoxemia. These may be accompanied by congestion, fever, irritability, and decreased feeding [4].

Viral infections that can cause pediatric pneumonia include and other viruses $[6,7]$.

The most common bacterial cause of pediatric pneumonia is Streptococcus pneumoniae bacteria [7]. Another possible bacterial cause is Mycoplasma pneumoniae, which usually causes atypical pneumonia [7]. 
A few other types of bacteria can cause pneumonia in children, including group B streptococcus and staphylococcus aureus [7].

Diagnostic tests for pneumonia may include pulse oximetry, complete blood cell (CBC) count, sputum and blood culture, serology, chest radiography, ultrasonography [8].

Initial priorities in children with pneumonia include the identification and treatmentofrespiratory distress, hypoxemia, and hypercarbia [9]. Grunting, flaring, severe tachypnea, and retractions should prompt immediate respiratory support [6]. Children who are in severe respiratory distress should undergo tracheal intubation if they are unable to maintain oxygenation or have decreasing levels of consciousness [9]. Increased respiratory support requirements such as increased inhaled oxygen concentration, positive pressure ventilation, or CPAP are commonly required before recovery begins [9].

High-dose amoxicillin is used as a first-line agent for children with uncomplicated community-acquired pneumonia. Second- or third-generation cephalosporins and macrolide antibiotics such as azithromycin are acceptable alternatives [9]. Combination therapy (ampicillin and either gentamicin or cefotaxime) is typically used in the initial treatment of newborns and young infants [9].

Children who are toxic appearing should receive antibiotic therapy that includes vancomycin (particularly in areas where penicillin-resistant pneumococci and methicillin-resistant $S$ aureus [MRSA] are prevalent) along with a second- or thirdgeneration cephalosporin [9].

Vaccination is the primary mode of prevention. Influenza vaccine is recommended for children aged 6 months and older [10]. The pneumococcal conjugate vaccine (PCV13) is recommended for all children younger than 59 months old. The 23-valent polysaccharide vaccine (PPV23) is recommended for children 24 months or older who are at high risk of pneumococcal disease [10]. According to WHO around 156 million people affected by pneumonia and most of these in developing country [11]. In fact, Sudan has high mortality rate $(112 / 1000$ live birth) and respiratory problems one of the contributing factors $[11,12]$.

\section{The rationale}

1. of this review is to provide one package as approach for pneumonia management in developing countries in general and Sudan in particular.

2. Lack of data regarding pneumonia in developing country general, Sudan in particular.

3. No guideline for the Sudanese context.

4. Variation in approach to management of pneumonia by different physician.
5. Under use of chest X-ray despite its feasibility.

6. Use of blood culture as diagnostic tool in emergerncy situation despite its limitation.

\section{The objective}

1. To reflect author experience in management of childhood pneumonia in Sudan.

2. To determine feasible, affordable approach to pneumonia in Sudan.

\section{Methodology}

Searching through PubMed for the author publication and review of publication by author in Sudan regarding management of pneumonia (Table 1).

The key words were: management of childhood pneumonia in Sudan.

\section{Other experience in childhood pneumonia management}

Some author's request $\mathrm{CBC}$ for toxic patient with severe pneumonia $[15,16]$, inflammatory markers are only used for prognostic purpose, however their value as predictive factors for positive blood culture not practiced [15-17], Chest X-ray for investigation of pneumonia although not recommended routinely as investigation [15-17], other considered it useful $[15,17]$, others considered chest X-ray indicated for febrile children with leukocytosis $[15,18]$ but indication for fertile patient and leukocytosis would be well understood science febrile and toxicity might suggest bacterial infection.

The association of inflammatory mediator with community acquired pneumonia is uncertain despite many studies [19], however Sudanese study [20] proved high C-reactive protein associated with positive blood culture in severe pneumonia.

Variation in adherence to guide line was observer in only $45 \%$ [10], This failure to adherence to guide line will lead to difference in duration of treat [21], which can affect the outcome, moreover, different regimen will open the door for affordability, side effect and increasing the burden of the disease.

Despite the global reduction in in deaths in under-five, however severe pneumonia presents a burden therefore anticipation of adequate approach and management is always urgently needed [22]. Sudanese study by Salih, et al. 2015, documented some factors can anticipated mortality from severe pneumonia such as age less than 18-month, malnutrition, dehydration, chest in -drawing, low hemoglobin, low albumin. High level of c-reactive protein as well as high blood urea [22].

\section{Discussion}

It is very obvious the burden of childhood pneumonia in developing country in general and specifically Sudan, can be 


\begin{tabular}{|c|c|c|c|c|c|c|c|c|c|}
\hline $\begin{array}{l}\text { Date of } \\
\text { the study }\end{array}$ & Citation & Sample & Area & Intervention & \multicolumn{2}{|c|}{ Positive } & \multicolumn{2}{|c|}{ Negative } & \multirow[t]{2}{*}{$p$ value } \\
\hline & & & & & No & $\%$ & No & $\%$ & \\
\hline 2012 & $\begin{array}{l}\text { Ali Salih, KEM, OA Wahb, and SA Ibrahim. } \\
\text { "Radiological Findings in Severe Pneumonia in } \\
\text { Children 1-59 Months in a Children's Hospital, } \\
\text { Khartoum, Sudan." Pediatr Therapeut } 2.117 \\
\text { (2012): 2161-0665. }\end{array}$ & 156 & $\begin{array}{c}\text { Khartoum } \\
\text { Children's } \\
\text { Hospital }\end{array}$ & $\begin{array}{l}\text { Investigation } \\
\text { 1.Chest X-ray }\end{array}$ & 73 & 46.8 & 83 & 53.2 & Significant \\
\hline \multirow{5}{*}{2015} & \multirow{5}{*}{$\begin{array}{l}\text { Salih, Karimeldin Mohamed Ali, et al. "Clinical } \\
\text { and Laboratory Potential Predictors of Blood } \\
\text { Culture Positivity in Under Five Children with } \\
\text { Clinically Severe Pneumonia-Khartoum- } \\
\text { Sudan." Journal of clinical and diagnostic } \\
\text { research: JCDR } 9.8 \text { (2015): SC04. }\end{array}$} & \multirow{5}{*}{189} & \multirow{5}{*}{$\begin{array}{c}\text { Khartoum } \\
\text { Children's } \\
\text { Hospital }\end{array}$} & 1.High WBC > 20000 & 124 & $66 \%$ & 65 & $34 \%$ & \\
\hline & & & & $\begin{array}{l}\text { 2.High C-reactive protein } \\
\text { (very high) }\end{array}$ & 119 & 63 & 70 & 37 & \\
\hline & & & & 3.C-X-ray & 99 & 52 & 90 & 48 & \\
\hline & & & & 4.Blood culture & 41 & 21.7 & 148 & 78.3 & \\
\hline & & & & Temperature more than 40 & 189 & 100 & 0 & 0 & \\
\hline \multirow[t]{3}{*}{2016} & $\begin{array}{c}\text { Salih, Karimeldin MA, et al. "Assessment } \\
\text { of treatment of community acquired severe } \\
\text { pneumonia by two different antibiotics." Journal } \\
\text { of clinical and diagnostic research: JCDR10.5 } \\
\text { (2016): SC06. }\end{array}$ & 132 & $\begin{array}{c}\text { Khartoum } \\
\text { Children's } \\
\text { Hospital }\end{array}$ & $\begin{array}{l}\text { Treatment } \\
\text { 1.Full recovery after } \\
\text { penicillin }\end{array}$ & 26 & 78.8 & 7 & 21.2 & Insignificant \\
\hline & & & & $\begin{array}{l}\text { 2.Full recovery after } \\
\text { Augmentin }\end{array}$ & 43 & $86 \%$ & 7 & 14 & Insignificant \\
\hline & & & & $\begin{array}{l}\text { 3.Full recovery after } \\
\text { ceftriaxone }\end{array}$ & 44 & 89.8 & 5 & 10.2 & Insignificant \\
\hline 2014 & $\begin{array}{l}\text { Salih, Karim Eldin M., et al. "Poor adherence } \\
\text { to the World Health Organization guidelines of } \\
\text { treatment of severe pneumonia in children at } \\
\text { Khartoum, Sudan." BMC research notes } 7.1 \\
\text { (2014): } 531 .\end{array}$ & 208 & $\begin{array}{c}\text { Khartoum } \\
\text { Children's } \\
\text { Hospital }\end{array}$ & $\begin{array}{l}\text { Adherence to } \mathrm{WHO} \\
\text { treatment(penicillin) }\end{array}$ & 39 & 18.8 & 169 & 81.2 & Insignificant \\
\hline
\end{tabular}

NB: Adopted from the Mentioned Journal.

\begin{tabular}{|c|c|c|c|c|c|c|c|c|c|}
\hline $\begin{array}{l}\text { Date of the } \\
\text { study }\end{array}$ & Citation & Sample & Area & Intervention & \multicolumn{2}{|c|}{ Positive } & \multicolumn{2}{|c|}{ Negative } & $\begin{array}{c}\text { Positive } \\
\text { predictive value }\end{array}$ \\
\hline \multirow{4}{*}{2015} & \multirow{4}{*}{$\begin{array}{l}\text { Salih, Karimeldin Mohamed Ali, et al. "Clinical and } \\
\text { Laboratory Potential Predictors of Blood Culture } \\
\text { Positivity in Under Five Children with Clinically } \\
\text { Severe Pneumonia-Khartoum-Sudan." Journal of } \\
\text { clinical and diagnostic research: JCDR } 9.8 \text { (2015): } \\
\text { SC04. }\end{array}$} & \multirow{4}{*}{189} & \multirow{4}{*}{$\begin{array}{c}\text { Khartoum } \\
\text { Children's } \\
\text { Hospital }\end{array}$} & 1. High $W B C>20000$ & 124 & $66 \%$ & 65 & $34 \%$ & $46.1 \%$ \\
\hline & & & & $\begin{array}{l}\text { 2. High C-reactive } \\
\text { protein (very high) }\end{array}$ & 119 & 63 & 70 & 37 & $44.3 \%$ \\
\hline & & & & 3.C-X-ray & 99 & 52 & 90 & 48 & $25.3 \%$ \\
\hline & & & & $\begin{array}{c}\text { Temperature more } \\
\text { than } 40^{\circ}\end{array}$ & 189 & 100 & 0 & 0 & $40.0 \%$ \\
\hline
\end{tabular}

NB: Adopted from the Mentioned Journal.

minimized by adopting relevant and excellent approach. Chest $\mathrm{X}$-ray which is simple and cheap tool for investigation can is helpful and should be considered which agreed on it by many authorities [13]. However proper posting interpretation of the radiological signs is highly needed. 1 . High $\mathrm{WBC}>20000$, High C-reactive protein (very high ( $\geq 8 \mathrm{mg} / \mathrm{l}$ ), C-X-ray signs and high fever of 40 degree or more are indicators of severe pneumonia in children. However, these are nonspecific $t$ signs of child hoods pneumonia, but it can predict blood culture positivity. Positive blood culture is the essential basis for treatment, however in developing countries, many factors like sophisticated laparotomy, well established laparotomy, sample transportation, prior use of antibiotic, availability of equipment, well trained personnel and the nature of the organism might make blood culture yield not gratifying. Predictively for blood culture positivity was seen in Sudanese experience as High WBC $>20000$, High C-reactive protein (very high $(\geq 8 \mathrm{mg} / \mathrm{l})$, Temperature more than 40 degree centigrade and positive chest X-ray finding with positive predictively for blood culture in $46.1 \%, 44.3 \%, 40.0 \%$ and $25.3 \%$ respectively. These factors, except chest X-ray that predict positive blood culture for children with pneumonia is in agreement with [14,23-30].
The treating doctor in Sudan using different regimen like penicillin which is recommended by WHO which is cheap and available, Augmentin, b-lactam inhibitors), (which is more expensive and ceftriaxone which is expensive. the Sudanese experience showed no significant difference in recovery rate regardless of the drug [23,31-33]. Finally, many studies recommended zinc sulfate with the antibiotic, regardless of the type will minimized hospital stay [34].

\section{Conclusion}

Simple chest X-ray which is cost effect can help in decreasing burden of pneumonia among children. High temperature, high WBC and C-reactive protein are good indicators for predictively of blood culture for children with pneumonia. Antibiotic treatment for childhood pneumonia weather that recommended by WHO, b-lactam inhibitors or $3^{\text {rd }}$ generation cephalosporin has the same outcome.

\section{Recommendation}

In emergency situation no need to waste time for sending blood sample for culture unless patient has high fever-reactive protein or high WBC, moreover chest X-ray can add much to the diagnosis of pneumonia. 


\section{Acknowledgement}

I would like to appreciate my colleague Dr. Abbas for valuable advices, help and advice and editing.

\section{References}

1. World Health Organization. "Revised WHO classification and treatment of childhood pneumonia at health facilities." Geneva: World Health Organization. 2014; 6-14.

2. World Health Organization. "Revised WHO Classification and Treatment of Childhood Pneumonia at Health Facilities-Evidence Summaries, 2014. Geneva: WHO. 2014.

3. Levels and Trends in Child Mortality: Report 2014. United Nations Inter Agency Group for Child Mortality Estimation. UNICEF, WHO, The World Bank, United Nations Population Division. New York, 2014.

4. Pediatric Pneumonia: Practice Essentials. Medscape. 2018.

5. Childhood Pneumonia. JAMA Network. 2017.

6. Pneumonia. Great Ormond Street Hospital for Children. 2011.

7. Pediatric Pneumonia: Etiology. Medscape. 2018.

8. Boggs W. Point-of-Care Ultrasound Diagnoses Pneumonia in Children Medscape Medical News. 2012

9. Bradley JS, Byington CL, Shah SS, Alverson B, Carter ER, et al. The Management of Community-Acquired Pneumonia in Infants and Children Older Than 3 Months of Age: Clinical Practice Guidelines by the Pediatric Infectious Diseases Society and the Infectious Diseases Society of America. Clin Infect Dis. 2011; 53: e25-76.

PubMed: https://pubmed.ncbi.nlm.nih.gov/21880587/

10. Pneumococcal Vaccination: What Everyone Should Know. Centers for Disease Control and Prevention. 2017.

11. Salih KEM, Bilal JA, Alfadeel MA, Hamid Y, Eldouch W, et al. Poor adherence to the World Health Organization guidelines of treatment of severe pneumonia in children at Khartoum, Sudan. BMC Res Notes. 2014; 7: 531.

PubMed: https://pubmed.ncbi.nlm.nih.gov/25123047/

12. WHO. Country cooperation strategy for WHO and Sudan: 20082013. World Health Organization. Regional Office for the Eastern Mediterranean; 2010.

13. O'Grady KAF, Taylor Thomson DM, Chang AB, Torzillo PJ, Morris PS, et al. Rates of radiologically confirmed pneumonia as defined by the World Health Organization in Northern Territory Indigenous children. Med J Aust. 2010; 192: 592-595.

PubMed: https://pubmed.ncbi.nlm.nih.gov/20477736/

14. Gove S. Integrated management of childhood illness by outpatient health workers: technical basis and overview. The WHO Working Group on Guidelines for Integrated Management of the Sick Child. Bul World Health Organ. 1997; 75(Suppl 1): 7-24.

PubMed: https://pubmed.ncbi.nlm.nih.gov/9529714/

15. Hopstaken R, Witbraad T, Van Engelshoven J, Dinant G. Inter-observer variation in the interpretation of chest radiographs for pneumonia in community-acquired lower respiratory tract infections. Clin Radiol. 2004; 59: 743-752.

PubMed: https://pubmed.ncbi.nlm.nih.gov/15262550/

16. Koster MJ, Broekhuizen BD, Minnaard MC, Balemans WA, Hopstaken $\mathrm{RM}$, et al. Diagnostic properties of C-reactive protein for detecting pneumonia in children. Respir Med. 2013; 107: 1087-1093. PubMed: https://pubmed.ncbi.nlm.nih.gov/23672994/

17. Díez Padrisa N, Bassat Q, Morais L, O'Callaghan Gordo C, Machevo S, et al. Procalcitonin and C-reactive protein as predictors of blood culture positivity among hospitalised children with severe pneumonia in Mozambique. Tropical Med Int Health. 2012; 17: 1100-1107. PubMed: https://pubmed.ncbi.nlm.nih.gov/22809300/

18. Michelow IC, Olsen K, Lozano J, Rollins NK, Duffy LB, et al. Epidemiology and clinical characteristics of community-acquired pneumonia in hospitalized children. Pediatrics. 2004; 113: 701-707. PubMed: https://pubmed.ncbi.nlm.nih.gov/15060215/

19. Shah SS, Dugan MH, Bell LM, Grundmeier RW, Florin TA, et al. Blood cultures in the emergency department evaluation of childhood pneumonia. Pediatr Infect Dis J. 2011; 30: 475-479. PubMed: https://pubmed.ncbi.nlm.nih.gov/21206393/

20. Díez-Padrisa N, Bassat Q, Machevo S, Quintó L, Morais L, et al. Procalcitonin and $\mathrm{C}$-reactive protein for invasive bacterial pneumonia diagnosis among children in Mozambique, a malaria-endemic area. PloS One. 2010; 5: e13226.

PubMed: https://pubmed.ncbi.nlm.nih.gov/20976241/

21. Carrol ED, Mankhambo LA, Jeffers G, Parker D, Guiver M, et al. The diagnostic and prognostic accuracy of five markers of serious bacterial infection in Malawian children with signs of severe infection. PLoS One. 2009; 4: e6621.

PubMed: https://pubmed.ncbi.nlm.nih.gov/19675669/

22. Salih KMA, AliBilal J, Karsani AH. Risk factors of mortality among children admitted with severe pneumonia at a reference hospital in Khartoum, Sudan. Am J Med Medi Sci. 2015; 5: 130-134.

23. Salih KM, El-Samani E, Bilal JL, Eldouch W, Ibrahim SA. Clinical and Laboratory Potential Predictors of Blood Culture Positivity in Under Five Children with Clinically Severe Pneumonia-Khartoum-Sudan. J Clin Diagnos Res. 2015; 9: SC04-7.

PubMed: https://pubmed.ncbi.nlm.nih.gov/26436013/

24. WHO. Programme of Acute Respiratory Infections. WHO Technical Advisory Group on Acute Respiratory Infections. Report of the Third Meeting, Geneva, 9-13 March 1987. Geneva: WHO; 1987. WHO/ RSD/87.37). http://whqlibdoc

25. Frayha $\mathrm{H}$. The Management of Acute Respiratory Infections in Children: Practical Guidelines for Outpatient Care. King Faisal Specialist Hospital and Research Centre; 1997.

26. Ribeiro CF, Ferrari GF, Fioretto JR. Antibiotic treatment schemes for very severe community-acquired pneumonia in children: a randomized clinical study. Rev Panam Salud Publica. 2011; 29: 444-450.

PubMed: https://pubmed.ncbi.nlm.nih.gov/21829969/

27. Salih KM, Bilal JA, Eldouch W, Abdin A. Assessment of treatment of community acquired severe pneumonia by two different antibiotics. J Clin Diagnos Res. 2016; 10: SC06-09.

PubMed: https://www.ncbi.nlm.nih.gov/pmc/articles/PMC4948494/

28. Ebeledike C, Ahmad T. Pediatric Pneumonia. StatPearls [Internet] StatPearls Publishing; 2020.

PubMed: https://pubmed.ncbi.nlm.nih.gov/30725625/

29. Hall CB, Powell KR, Schnabel KC, Gala CL, Pincus PH. Risk of secondary bacterial infection in infants hospitalized with respiratory syncytial viral infection. J Pediatr. 1988; 113: 266-271. PubMed: https://pubmed.ncbi.nlm.nih.gov/3397789/

30. McIntosh K. Community-acquired pneumonia in children. New Engl J Med. 2002; 346: 429-437.

PubMed: https://pubmed.ncbi.nlm.nih.gov/11832532/

31. Nohynek H, Valkeila E, Leinonen M, Eskola J. Erythrocyte sedimentation rate, white blood cell count and serum C-reactive protein in assessing etiologic diagnosis of acute lower respiratory infections in children. Pediat Infect Dis J. 1995; 14: 484-490.

PubMed: https://pubmed.ncbi.nlm.nih.gov/7667052/ 
32. Kapanadze N, Pantsulaia I, Chkhaidze I. Cytokines profile and its connection with disease severity in community-acquired pediatric pneumonia. Georgian Med News. 2018: 103-108.

PubMed: https://pubmed.ncbi.nIm.nih.gov/30618399/

33. Di Pietro $P$, Alberighi ODC, Silvestri M, Tosca MA, Ruocco A, et al Monitoring adherence to guidelines of antibiotic use in pediatric pneumonia: the MAREA study. Italian J Pediatr. 2017; 43: 113. PubMed: https://pubmed.ncbi.nlm.nih.gov/29273072/

34. Bose $\mathrm{A}$, Coles $\mathrm{CL}$, John $\mathrm{H}$, Moses $\mathrm{P}$, Raghupathy $\mathrm{P}$, et al. Efficacy of zinc in the treatment of severe pneumonia in hospitalized children $<2 y$ old. Am J Clin Nutr. 2006; 83: 1089-1096. 